\title{
Culture Agonistes: Social Differentiation, Cultural Policy and Cultural Olympiads
}

'Olympism ... exalting and combining in a balanced whole the qualities of body, mind and will' - Pierre de Coubertin

'In a film I watched recently, an unnamed poet remarked "art can make strangers love each other", which I'd happily adopt as my aspiration for the Cultural Olympiad. Ideally, experimentation will be encouraged, while snobbishly outdated boundaries between art forms and cultural pursuits will be broken down' - Sandra Hebron, artistic director, London Film Festival

'Do sport and culture have anything in common in terms of the Olympics? ... [A]t the launch of the Olympic offering from the Museums Libraries and Archives Partnership, a gymnastics gold medallist declared that "the link between sport and culture has never been stronger!" What planet is she living on?'- John Tusa, former managing director, Barbican Centre, London ${ }^{1}$

\section{Introduction}

The phrase 'Cultural Olympiad' is seemingly one of the more odd terms associated with the Olympic Games. Striving as it does to yoke together the cultural with the sportive, the artistic with the physical, and the intellectual with the corporeal, this phrase seeks to unite features of human life that have been very much divided from each other within Western modernity, at the same time as it risks being regarded as a complete contradiction in terms. Both the phrase itself and the cultural institutions and events which it animates, dramatically express some of the tensions that derive from attempts to conjoin 'culture' and 'arts' on the one hand, and 'sports' on the other in a historical period such as ours, in which the entities these signifiers depict seem to be utterly antithetical to each other. This raises the question of how any cultural policies predicated upon melding together the worlds of arts and sports could ever have any hope of succeeding.

As other papers in this edition of the journal testify, the arts-culture-sport interface is becoming an ever more important conceptual space within cultural policy debates and practices. Just as in contemporary policy thinking arts and 'culture' seem to be prime factors to be mobilised for the purposes of promoting urban regeneration and social inclusion, so too might sports, regarded as part of a wider 'culture', be put to some of the same uses by government and related agencies (Hughson, 2004). If the artsculture-sport interface is to become a key site for policy interventions in the future, it would be instructive to consider previous examples of how such an interface has hitherto been conceptualised and operationalised. The case of the cultural events tied to successive Olympiads provides a major case study in this regard, as such events are perhaps the most major historical examples of what has happened when planners and officials have endeavoured to couple arts, culture and sports in the hope of achieving certain outcomes. The generally vexed history of culture at the Olympics culminating in the recent phenomenon of four year-long 'Cultural Olympiads' - has a number of salutary lessons for those who wish to regard culture and sports as conceptually and pragmatically complementary rather than as antithetical. 
This paper will draw out such lessons by considering the history of 'culture' at the Olympics, how the relations between 'arts' and sports' has mutated over time, and how those mutations reflect and embody broader changes in cultural context, social organization and political imperatives. In order to provide a coherent analytic thread to the argument being pursued, I will develop a historical-sociological perspective on such matters, centred around the key notion of 'structural differentiation'. A key theme of most classical sociological theory - to be found in the work of, for example, figures as various as Karl Marx, Emile Durkheim and Herbert Spencer - the central idea of accounts of structural differentiation is that the increasing social complexity of Western modernity over the last several hundred years involves shifts in social structure away from social order being made of a few simple parts, all overlapping with each other, to a condition characterised by a multiplicity of components all distinct and relatively insulated from each other (Sztompka, 1993) Thus as law, education, politics, art and so on become distinct social institutions (or social 'spheres' and 'fields'), they get decoupled from religion, the social sphere that originally encompassed them all. Within each sphere are specialists who engage in specialised work in that sphere only: lawyers, teachers, politicians and civil servants, artists, and so on. This increasing specialisation in the division of labour was noted by Karl Marx, who described how increasingly mental and conceptual labour (e.g. architectural design) were divided, and kept in separate social spheres, from physical labour (e.g. building a wall). This began to have profound effects on how people conceived of themselves, of their capacities and of their practices, both in work and in leisure. Unlike in ancient Greece, the birthplace of the original Olympics, where a strong distinction was not made between 'aesthetic' and 'sportive' matters (because arts and sports did not occupy distinct, isolated social spheres), by the mid-nineteenth century a firm conceptual divide had been opened up between 'arts' (and 'culture' in the sense of 'high culture') and 'sports', and this distinction was both produced, reinforced and policed by each of these areas of human endeavour being located in separate social spheres that had little interaction between each other (Williams, 1981).

This separating out of 'arts' and 'sports' is a social-structural legacy from the nineteenth century which the founders of the modern Olympic games explicitly sought to overcome. Yet the history of 'culture' at the Olympics is in many ways a story of how many well-intentioned and idealistic efforts to bridge this gap have foundered precisely because the gap has been so wide, both ideationally and in terms of modes of social organisation. In what follows, I will outline the main contours of this vexed history, first of all examining early attempts to bridge the divide by means of policy-making; second, I will home in on the modern-day phenomenon of Cultural Olympiad, taking the case of the Sydney 2000 games as a prime example of the problems planners face in yoking arts and sports together for particular ends; third, I will present the emerging dynamics of the planning of cultural events for the London 2012 games, and I will show how in this case, history threatens to repeat itself in the guises of organisational flaws, chronic under-funding and an inability to see the underlying issues that are at stake. I conclude by proposing some ways in which future events might be able to escape, at least in part, from the shadows cast by Olympic cultural events of the past.

\section{Arts, Culture and the Olympics}


The arts have always had a rather peculiar, if not to say somewhat strained, relationship with the Olympics. When Pierre de Coubertin established the modern Olympics in the 1890s, he was concerned not only to revive the games as a purely sporting event, but also to rekindle what he took to be the entirety of the ancient Olympic festival. Ancient Greek social structure and culture was of course nowhere near as differentiated and divided into autonomous realms as was Europe in the later part of the nineteenth century. The original Olympics had in fact begun in the sixth century BCE as a singing contest dedicated to the god Apollo; athletics competitions (agones) were only added at a later date Gold and Revill, 2007). Thus the totality of the ancient Olympics in their heyday was characterised by a cultural complex of 'arts' and 'sports' together (although these terms themselves are modern signifiers which point to differentiated social spheres the like of which did not exist at this time), fused together by a web of religious belief. Consequently, when de Coubertin sought to rekindle the 'Olympic spirit' in modernity, his aim was to 'take up the ethos of the panegyris from the classical festival - a festive assembly in which the entire people came together to participate in religious rites, sporting competitions and artistic performance' (Gold and Revill, 2007: 59).

On this vision, not only were the arts to be present at each Olympiad, they were central means of expression of its core values, namely the pursuit of excellence (in a wide range of human endeavours) on the one hand, and a fostering of harmonious relations between nations on the other. In effect de Coubertin was proposing a form of Olympiad which was quintessentially 'modern' in that the values it promoted were secular, but which retained, against the powerful differentiating tendencies of modernity, key elements of the undifferentiated complex of sports and arts which had characterised ancient Greek experience. The modern Olympics were to be based upon an alliance of 'athletes, artists and spectators' (Muller, 2000: 612), the former two groups having come in modernity not only to be socially separated from each other, but also to be mutual antagonists, the one group championing the physical values of the body - sportive prowess, physical strength, and so on - and the other upholding the intellectual values of the mind and the soul (Williams, 1981). Ancient Greek culture had not made such a profound distinction between mind and body that modern culture did, and de Coubertin's attempt to resurrect the Olympics as a fusion of the sportive and the artistic was self-consciously an endeavour to heal what he, and many others of the time, thought of as a damaging rift in both human social organisation and the individual human being's sense of self. The modern Olympics therefore was intended to be as much a spiritual exercise as a sportive one; indeed, the point was in part to show that the spirit and the body were united rather than separate essences. But as de Coubertin himself knew very well, reanimating the Greek spirit of the Olympics was much harder than merely restarting the tradition of four yearly sporting events (Muller, ibid.).

The efforts first of de Coubertin and his circle, then of their successors, to instantiate in modernity a deeply non-modern understanding of the spiritual and artistic dimensions of sport, were inevitably going to run into difficulties. But the problems the artistic and cultural sides of the Olympiad were actually to face were more severe than perhaps their initiators had ever envisaged. The first major endeavour to engage and connect the two divergent worlds of sport and art was the setting-up of an Advisory Conference on the 'Incorporation of the Fine Arts in the Olympic Games 
and Everyday Life', held in Paris in 1906. The meeting recommended that competitions be set up in the 'pentathlon of the arts', namely music composition, literature, sculpture, painting and architecture, and these competitions were to exist on an equal footing with the sporting competitions (Muller, ibid.). This was in addition to the general 'cultural programme' of arts events that hosts cities would be expected to put on for the entertainment of visitors during the period of the Olympiad. Initially, it had been hoped to begin arts competitions at the London games of 1908, but insufficient time was allocated to organise these and the plan was abandoned. More successfully, the Stockholm games of 1912 had a substantial cultural programme that occurred at the same time as the sporting events, much of the programme (e.g. opera performances) being aimed at stimulating tourism to the Swedish capital, an early precursor of the general trend of Olympics cultural programming after World War II. Indeed, this initial mixture of arts competitions and cultural programmes set the pattern for the cultural dimension of the summer games, right through to the post-war London event of 1948 (Gold and Revill, ibid.).

The arts competitions in this period tended to have more downs than ups. For example, the games in Paris in 1924 involved a musical composition contest that was judged by no lesser luminaries than composers such as Bartok, Ravel, Fauré and Stravinsky. Although the eminence of the judging panel seems to betoken that in this particular art world at least, Olympic arts were being taken seriously, the panel clearly did not think much of the (relatively few) entries and refused to award any prizes (Gold and Revill, ibid.). A mixture of factors were responsible for the ultimate demise of the arts competitions, which were dropped off the Olympic agenda after the London 1948 games, to be subsequently replaced by non-competitive 'arts festivals'. At the root of all of these specific factors was the apparently now wholly unbridgeable divide between the worlds of arts and sports. This was responsible for specific phenomena such as avant-garde artists spurning the arts competitions as hopelessly outmoded in terms of the styles that were permitted to competition entries; as overly constricting artists (especially in a period when the avant-garde was breaking with all notions of 'representation') in terms of dictating what the subject matter was to be usually some sport-related theme; and generally as being utterly 'bourgeois' and conformist in nature.

In the terms afforded by the French sociologist Pierre Bourdieu (1993), Olympic arts were felt by contemporary artists, especially those in avant-gardes, to be very much beyond the pale, because they were thoroughly dominated by 'heteronomous' principles (such as the bourgeois idea of competition, and a shackling of artistic freedom both stylistically and substantively) when 'real art' worked within no such confines, and operated only according to its own 'autonomous' principles, the latter situation summed up in the programmatic slogan of 'art for art's sake'. In essence, leading artists of the inter-War period thought the idea of Olympic arts hopelessly jejune, and something they would gain no credit for being involved in. The contemporary art world was organised in such a way that one could not gain sufficient artistic recognition and kudos by being involved in an event as heteronomous as Olympic arts. Thus while the musical avant-garde of the 1920s could just about be persuaded to act as judges for the Olympic music competition, none of these leading lights themselves would ever have thought to have entered a piece into competition themselves - it would have been far beneath their dignity to do so. 
In addition, as Stanton (2000) has argued, it was not just the art world's rejection of the Olympics that was involved here. It was also the case that on the side of the International Olympic Committee (IOC), there were concerns about the Olympic ideal of amateurism in sport being sullied by the presence in the arts competitions of professional artists. Thus just as the values of the arts world were imperilled by the introduction of an explicitly competitive element being introduced into artistic practice, so too were the values of the sportive world of the Olympics potentially sullied by the importation of 'professionalism' (here meaning being monetarily remunerated for one's activities) into a world of amateurs and amateurism. In both cases, it was fear of pollution by the importation into a given field of a heteronomous principle that threatened the 'sacred' values of that field - 'art for art's sake' in the one case, 'sport for sports sake' in the other - that was at the heart of the problem. By the 1920s, both arts and sports occupied social worlds governed by sets of values that had become radically incompatible with each other, with the result that the merger of the two worlds through the medium of arts competitions had become doomed to failure.

For these sorts of reasons, then, the arts competitions, intended to meld the sportivecompetitive elements of ancient Olympia with the cultural-aesthetic facets of the later, were disposed of, because the differentiated social system of artistic production could not accommodate the principles of the Olympics into its own characteristic mode of functioning, and vice versa. But if 'arts' and 'sports' were uneasy bed-fellows, a more companionable partnership was possible between 'sports' and 'culture' where the latter was taken to mean the 'whole way of life' of a given nation, rather than the 'high arts' alone (Williams, 1977). The general 'cultural programme' that had been initiated before World War I, became an ever more prominent feature of successive Olympiads, precisely because it could be used as a tool by host states to promote particular interests. While Stockholm had regarded its programme as primarily a tourism-boosting mechanism, the Nazi government that hosted the Berlin games of 1936 regarded its vastly expensive and ambitious cultural events as offering a chance to present to the world an idealised view of life in the emerging Reich. For example, the 'Olympic Youth' spectacle involved 10,000 performers, moving in rhythm to a score composed in part by Carl Orff. The theme of 'Aryan culture' took centre stage, as the Nazi regime depicted the racially pure idyll that was being constructed under the benevolent gaze of Hitler (Hilton, 2008).

It is a curious historical fact that in many ways the 'Nazi Olympics' of 1936 set the formal template for later cultural programmes at the Olympic games, even if their substantive content was thoroughly decried after 1945. An increasingly massive programme, thoroughly tied to the aims and ambitions of state elites, concerned to demonstrate to the wider world the most positive side of the host country - all these trends were accentuated in the post-War period, sometimes in the guise of Cold War propaganda (as per the highly ideologically-loaded programmes of the Moscow games in 1980 and the Los Angeles event in 1984), and thence in the more liberal, inclusive, multiculturalist rhetoric of the 1990s and onwards (as per for example, Sydney 2000, as we will see shortly.). From the mid-1950s onwards, it was enshrined in the IOC's Charter that the host nation's Organising Committee, would be obliged to put on a substantial cultural programme that celebrated 'Olympic values' through the medium of cultural festivities. 
It is particularly interesting to note in this regard that the Charter was amended at this point to stipulate that 'the programme shall be of an equal standard and held concurrently and in the same vicinity as the sports events. It shall receive full recognition in the publicity released' by the Organising Committee (cited at Gold and Revill, ibid. 71). This stipulation was the IOC's mid- $20^{\text {th }}$ century reinvention of de Coubertin's original endeavours to unites 'arts' and 'sports', but with the attempted unification now being between a more generally conceived 'culture' and sports. As we will see below, subsequent Olympic cultural programmes have often failed to meet the desiderata as to them being of the same standards and gaining equal publicity to the sportive events. Moreover, one of the problems that has bedevilled cultural programmes over the last fifty years or so is that, despite the above stipulation, there remains a lack of clear guidelines from the IOC as to nature of such programmes, how they are to be delivered, and by what criteria their success - or otherwise - is subsequently to be evaluated (Garcia and Miah, 2005). Local organising committees have thus often been unclear as to what it is they are supposed to be doing on the cultural side, and have often not taken the cultural programme as seriously as the above mandate requires, because it is also not clear what sanctions there might be for putting on a poor set of cultural activities. We will revisit these issues below.

Despite these ambiguities, one thing was clear - once the cultural dimension was defined in this way, it could be deployed in various ways by state elites, in manners more tractable to political manipulation than those afforded by the more inflexible term 'arts' and the realm to which it belongs, namely the relatively autonomous social sphere of the art world. As the cultural studies scholar Tony Bennett.(1998) has noted, the 'culture' of a given nation or group is less an ontological reality and more a category that can be used to categorise certain things in certain ways (e.g. defining particular practices as 'traditional' and thus culturally 'authentic') and then to deploy these things for certain purposes (e.g. to present such practices as part of the state's cultural patrimony, to use them for propagandistic ends, or to commercialise them as part of the state's tourist industries). By the 1980s, it had become established practice for Olympic cultural programmes to involve often uneasy assemblages of 'Olympic values' - peace among all nations, the idea that taking part is more important than winning, and so on - with the tendentious cultural-political messages of the host national government and/or the host city (the city rather than the whole country being the entity that is presented, branded and 'sold' becoming a more pronounced trend from the Barcelona games of 1992 onwards).

\section{Arts and Sports United? The Case of Sydney 2000}

A further strange paradox in the curious history of the relations between arts, culture and sports at the Olympics is that as the cultural dimension of Olympiads has expanded greatly in the last two decades, the media and public presence of this dimension has become ever more fragmented. While the increasingly spectacular Opening Ceremonies - part of the package that each local organising committee must put on as part of its contract with the IOC - gain ever more media attention, other parts of the cultural programme can gain hardly any publicity and public recognition at all. This situation is in part due to the expansion of the scope and chronology of the cultural programme that was instituted by the organising committee of the Barcelona 1992 games, and which has been followed ever since. The Barcelona programme 
introduced the notion of a four year-long 'Cultural Olympiad', which would run in the three years prior to the games and would culminate in an Olympic Festival taking place in the year of, and during, the Games themselves. The goals of the Cultural Olympiad 'tend to mix a strong domestic arts-related agenda of audience development and capacity-building in the arts sector with the desire to have an international dimension that promotes the city's Olympic and cultural role outside the host nation' (Gold and Revill, 2007: 76).

The Cultural Olympiad of the Sydney Olympics in many ways exemplifies the potential benefits, and plenitude of pitfalls, that accrue from having a four year cultural programme. The Sydney Cultural Olympiad comprised of four separate yearlong festivals. In year 1 (1997), there was the 'Festival of the Dreaming', a depiction of Australian aboriginal culture. In year 2 (1998), there was an event called 'A Sea Change', which was intended to celebrate contemporary multicultural Australia. In year 3 (1999), the programme that was staged was called 'Reaching the World', involving touring productions that went around different parts of the world to promote both Australian culture and the Olympiad itself. Finally, in year 4 (2000), the year of the games themselves, there was the Olympic Arts Festival, entitled 'The Harbour of Life', which showcased and promoted the 'best of Australian art'. This latter event lasted for six weeks, considerably shorter than analogous arts festivals in Barcelona in 1992 (which lasted 3 months) and Athens 2004 (which went on for seven months).

Possibly the most successful component of the Sydney programme was its first part, the 'Festival of the Dreaming', the celebration of aboriginal culture which took place in Sydney in the autumn of 1997. Given 'white' Australia's hitherto less than progressive attitudes towards aboriginals and their culture, the Festival of the Dreaming, being the country's first major festival of aboriginal art, was hailed in many quarters as finally having put the latter on the Australian cultural map, as something to be both respected and understood as an essential component of the continent's history and of Australia's present-day socio-cultural constitution. By taking aboriginal culture seriously for the first time in a planet-wide presentation of what Australia is and what it aspires to be, the Festival of the Dreaming was well placed to impact upon the thematic content of the Opening Ceremonies in 2000, aboriginal life and art being prominently displayed in the opening events. Nonetheless, there was quite a lot of negative press coverage in the months after the opening ceremony, to the effect that aboriginal culture had in fact been represented 'through European eyes' rather than through a cultural prism favoured by aboriginal people themselves, leading to accusations of colonial modes of representation continuing to underpin the apparently politically progressive presentation of aboriginal life and art that the Festival of the Dreaming had pioneered. Despite these criticisms, it remains the case that one of the notable features of the Sydney cultural programme was that it arguably managed to pioneer new forms of (self)consciousness among non-aboriginal Australians vis-a-vis aboriginal culture, which in turn started to affect how Australia and Australian-ness was perceived internationally. This probably counts as one of the more successful components of all the Cultural Olympiads held since 1992, even if the success has to be viewed as a qualified one (Cashman, 2006).

As regards other features of the Australian case, the cultural policy analyst Beatriz Garcia undertook at the time a series of studies of the Sydney events, and it is her 
invaluable work in this regard which animates this section of the paper. Garcia has shown in some detail many of the problems that undermined the rest of the Cultural Olympiad beyond its aboriginal culture components. One problem concerned the four year length of the Cultural Olympiad. While the expansion of the arts programme from a short period covering the run-up to, and duration of, the sportive events, to a lengthy time-scale beginning three years before the sports events, provides opportunities for long-term strategising, it also has downsides, not least that a programme that is elongated over this time-frame can succumb to a lack of clarity about the messages being given out to the public. While the Festival of the Dreaming had a clear conceptual focus, other elements in the programme were more thematically vague and opaque - particularly, one could argue, the now almost obligatory state-sponsored 'celebration' of the liberal shibboleth of 'multiculturalism', a signifier increasingly not only hackneyed but possibly meaningless. Relatedly, another problem that Garcia's work uncovered involved the running of the cultural programme by governmental and arts world elites. Especially as regards the arts festival held in 2000, grass-roots arts and community culture groups claimed they had been marginalised by the elite planners, with the alleged result that many of the arts activities were focused on the Opera House (a bastion of high cultural elitism, according to this view) and the city centre, with the suburban (often working class) areas where the sporting events were being held being witness to hardly any activities at all. Thus just as the planning of Cultural Olympiads is problematised by the divergences between the fields of arts and sports, so too are the divisions and bifurcations endemic within the former field itself - between better and worse-funded institutions, between high arts and community arts, and so on - liable to be reproduced within, and to problematise, Olympic cultural programming.

At a directly material level, Garcia notes that a recurring feature of all Cultural Olympiads which very much characterised the Sydney case, involved severe cuts in funding from the amounts originally promised to the local organising committee by national, regional and city governments. While year 1, the Festival of the Dreaming, operated within the original budget set, funding was slashed for events in years 2 to 4 . Thus while the opening ceremony, which lasted for a few hours at most, was given \$Aus 65 million, the four year programme had its budget cut from an initial sum of \$Aus 50 million down to a mere \$Aus 21 million. This had severe repercussions for the scope of events that could be put on in years 2 to 4 . One corollary of the budget cut was that opportunistic re-branding began to occur, re-labelling as somehow 'Olympic-related' events that were going to happen anyway. The slashing of the budget generally meant that promises that had been made in the original bid for Sydney to hold the games were not and could not be kept, again a recurring feature of cultural Olympiads since their inception (for example, the cultural budget of the Atlanta Olympiad in 1996 was cut from \$US 40 million to \$US 25 million).

At a more profound level, one has to ask why there seems to be such a strong tendency for arts and cultural programming to take a monetary hit when budget conditions become choppy. It seems to be an endemic feature of the planning of most contemporary large-scale projects that budgets that seemed 'plausible' before work began soon seem to be wildly inadequate as the costs of building materials and labour sky-rocket during the construction of crucial infrastructure such as new athletics stadia. Under such conditions, cultural programming budgets seem to be an easy resource to ransack, not least because in the context of the Olympics as we noted 
above, the IOC is vague both about what the cultural programme has to involve, what its scope must be, and how success or failure is to be evaluated post-event. Cutting the cultural budget seems to have little or no repercussions for local organisers from the IOC, so if this helps out with covering costs elsewhere, the prevailing view seems to be 'so be it'.

This point connects to other problems identified by Garcia. Whether a given games is subsequently deemed successful or not seems in the eyes of the key players involved to have little or nothing to do with the cultural programme, except for the opening ceremonies, which are deemed crucial. The Australian organisers were thus in their own terms wholly justified in spending \$Aus 65 million on the opening ceremonies while allocating just \$Aus 21 million to the three years of events that preceded them, because while the former was crucial as a media-created shop-window on and for Australia, the latter would be experienced by a tiny number of people in comparison to the vast global TV audience watching the opening ceremonies (Garcia and Miah, 2005). In addition, despite the IOC's rhetoric as to the Olympics being about the fusion of 'sports' and 'culture', media corporations and other key institutions such as corporate sponsors overwhelmingly regarded the Olympics as a sports-only event, completely devoid of the 'artistic' and 'spiritual' elements so prized by de Coubertin (Girginov and Parry, 2005). The IOC has been largely ineffective both in conveying the original Olympic message in this regard, and in compelling media and sponsoring organisations even to at least pay lip-service to it. As the classical sociologist Max Weber might have put it, the highly rationalistic, money-oriented, 'disenchanting' gaze of large capitalist bureaucracies strips away any residual spiritual or nonpragmatic elements from the objects it alights upon, and the modern Olympics is no exception. Given the vast sums of money to be made from a wholly de-spiritualised realm of sports, it is not at all surprising that the Olympic rhetoric of arts-and-sportsunited cuts little ice with captains of industry, advertising executives, and the controllers of global media, and it is these broad socio-cultural reasons, characteristic of late modern global capitalist accumulation, that are responsible for the lack of respect accorded to cultural programming budgets. 'Culture' has become the very poor relations to a globalized, mediated, profit-oriented sports industry, regardless of what the remaining proponents of the Olympic doctrine of amateurism may find to object to in this state of affairs.

In addition to these more general matters that would in the present day affect any Cultural Olympiad, Garcia (2001) also found some more specific reasons why the Sydney cultural programme was subject to serious problems. Tellingly, these issues also derive from the differentiated nature of different fields of human activity. Not only were the local and international media generally uninterested in cultural events, being almost wholly focussed on the sporting events, it was also the case that this media apathy was reinforced by Sydney's own administrative arrangements. The press and publicity department for the cultural programme was completely separate from the analogous department for the sportive events, and was housed in a different part of town. Thus even in the unlikely event that sports-oriented journalists wished to cover arts and culture-related stories, this task was made difficult for them by having to engage with a different bureaucracy from the one they had become accustomed to dealing with. As it happened, very few journalists actually made the effort to cover non-sports stories, no doubt because such an activity would have led to some quizzical reactions by their editors. Consequently, international press coverage of the 
Olympic Arts Festival which ran during the games was very limited, an opportunity to showcase contemporary Australian cultural production being significantly missed as a result. Likewise, but at a more general level, Garcia found that the organising bureaucracy of the cultural programme was poorly coordinated with the organisation responsible for sporting events. With each 'sector' having different administrative apparatuses, the problems attendant upon the differentiation into different social spheres of 'arts' and 'sports', issues characteristic of modernity in general, was reproduced at the more micro-level of Sydney's organisational structures. Once again we see the organizational dilemmas that can occur in attempts to make 'arts' and 'sports' work together, when the broader societal context is one which is characterised by the division of these entities and the generally effective insulation of these spheres by the means of institutional policing of their boundaries.

\section{Sports Over Arts? The Emerging Case of London 2012}

When in 2005 London won the bid to host the 2012 Olympics, it was widely reported that one of the main reasons that the IOC had chosen the UK capital was because of the particular strength of its proposals for the Cultural Olympiad. Once London had been selected, organising officials were not slow to play up the scale of London's proposals. For example, these were presented by the London Organising Committee's Director of Culture Bill Morris as "the first time any host city has created a Cultural Olympiad as inclusive and far-reaching" (London2012, 2007). Likewise, David Lammy, a UK government Culture Minister, proclaimed that the London cultural programme would be 'the biggest Cultural Olympiad that has ever been proposed'.

The aims of the London Cultural Olympiad very much mesh with wider New Labour cultural policy imperatives, which are themselves a mixture of orientations towards boosting the money-making capacities of British 'culture industries', and fostering social inclusion through encouraging access to, and participation in, arts-related activities (Hughson and Inglis, 2001). Thus the aims of the Cultural Olympiad, as stated in Department of Media, Culture and Sport documentation are

1) Augmenting participation. Here the aim is to encourage 'people of all ages to participate in cultural activity', and to foster 'the Olympic ideal of people achieving their potential through culture, education and sport', a nod in the direction of Coubertin's original vision. In this regard, there is a 'special focus on youth', aimed at encouraging the social inclusion of youth through the promotion of community-based arts activities.

2) The boosting of economic benefits \& skills. Just as the Olympics overall is meant to play a large role in regenerating impoverished areas of East London, where the main stadium facilities and Olympic village are to be located, so too is the Cultural Olympiad meant to showcase and develop East London's arts scene. Local authority briefing papers (London Councils, 2007) indicate that the area is home to a claimed 10,000 artists, and the cultural activities taking place under the auspices of the Cultural Olympiad are meant to improve cooperation and coordination between existing arts organisations in the area, as well as to put East London even more on the global cultural map as a site of artistic and cultural industry innovation. 
3) Promoting identity. The London bid noted that London is one of the most ethnically and culturally cosmopolitan cities in the world, and the Cultural Olympiad was intended both to 'reflect London's ethnic \& social diversity', as well as to promote pride amongst Londoners as to this state of affairs. This aim in many ways is London's version of the now typical 'celebrating multiculturalism' theme that is often invoked for large-scale cultural events, and was deployed by Sydney as part of its Olympic self-representation.

4) Selling a new image. The final component of the London bid was for the Cultural Olympiad was to act as a re-branding exercise in terms of (re-)shaping global perceptions of both London and the UK as whole (The Guardian, 2007). Precisely what that re-branding involves has not to date been made clear, but government sources have taken pains to point out that it will not herald a resurrection of the nowhackneyed 'cool Britannia' imagery that was new Labour's main attempt to reimagine Britain in its own image in the early years of Tony Blair's primeministership.

Beyond the mandatory opening ceremonies, the London bid contains two key streams of Cultural Olympiad events. The first are 'bid projects', and these include such events as a Youth Music project, a World Cultural Festival, a World Festival of Youth Culture, a Disability Arts and Sports series of events, a 2012 carnival, commissioning artworks in public spaces, an International Shakespeare Festival, and Olympic Proms at the Royal Albert Hall. While most of these activities are London-centred, the second stream of events involves a UK-wide cultural festival that is intended to be UK-wide in scope and to involve projects in all the English provinces, as well as possibly, Scotland, Wales and Northern Ireland (DCMS, 2007b).

Once it was announced, the Cultural Olympiad programme raised many of the same sorts of controversies that had already been heard in Sydney. Parts of the programme were simultaneously denounced as both elitist (e.g. funding for the Shakespeare festival was alleged to favour the elite Royal Shakespeare Company and Globe Theatre over smaller, community-oriented theatre groups) and as populist (e.g. there would be no funding for more 'challenging' art, and arts-oriented tourists would stay away from London during the Games because of their disdain for rowdy groups of sports fans).

But at a deeper level than these predictable sorts of complaints, it is noteworthy that the London organising committee and the UK government have sometimes endeavoured to justify their approach by framing their activities in terms of de Coubertin's original rhetoric. Speaking in 2007, the UK government Culture Secretary Tessa Jowell explicitly tried to present the London Cultural Olympiad as being directly and explicitly inspired by the vision of Olympism as a unification of arts and sports:

Coubertin spoke of the Olympics having an aspiration 'to an ideal of a higher life, to strive for perfection'; and to glorify beauty by the 'involvement of the philosophic arts in the Games'. The Ancient Greeks too saw the Olympics as a celebration of body and mind, and the Muses were present at the Ancient Games, because, in the view of the Greeks, what you did in pushing your body to perfection had to be matched by pushing your mind and spirit too - through poetry, the representation of physical perfection and aspiration, and through drama ... The matching of physical excellence with cultural excellence. It's what 
the Greeks expected. It's what Coubertin dreamed of. I'm determined that London 2012 will make it a reality (DCMS, 2007a).

Jowell's presentation of New Labour's Olympic cultural agenda certainly strikes an eloquent note. It implies that arts organisations and sporting bodies will be treated equally in the division of resources to pay for the London Olympiad. Here we encounter an interesting paradox. New Labour's cultural policy rhetoric pays lipservice to ideas of 'artistic excellence'. But generally speaking, in the New Labour worldview 'arts' are subsumed into a broader definition of 'culture' which stresses the instrumental benefits of cultural production in boosting Britain's economy, and of cultural participation in combating social exclusion amongst disadvantaged groups (Hughson and Inglis, ibid.). Conceptually speaking, on this view 'arts' can be put on the same ontological footing as 'sports', because both are equally forms of 'culture' that can be put to the instrumental purposes of producing profits and stimulating 'participation'. This apparently 'democratic' and anti-elitist thinking is embodied in the fact that the relevant government department for formulating policies is called the Department of Culture, Media and Sport - the three components of this unit's remit apparently all being granted equal status. As Hughson (2004) has noted, this has potentially paved the way for a possible series of deeper rapprochements between the worlds of 'arts' and 'sports', at least at the level of the apparatuses of government. In this sense, the DCMS structure seems like an interesting and potentially productive means of bridging the institutional and conceptual divides between the artistic and sportive realms that have been indicated above.

But the DCMS's apparent potential for bridging and reconciling this divide has been seriously undermined by major problems in funding the London games, a situation seemingly endemic to all projects of this sort. As of late 2007, a serious funding crisis had become apparent, with costs rising from a budgeted UK£2 billion to $£ 9$ billion. In response to this, the government indicated that the National Lottery - the source of a major part of UK government arts funding - was to contribute UK£2.2 billion to the Olympics, rather than the figure of UK£1.5 billion as had originally been planned, leading to potential serious funding crises across the UK arts sector. The government also announced the diversion of some UK£112 million from Arts Council England to pay for the construction of Olympic infrastructure. Likewise, and for similar reasons, the Heritage Lottery fund lost some UK£161 million in funding (Calvi, 2007a). It was also reported at this period that such government money as there was would go to the opening ceremonies and related events (a repeat of the situation in Sydney), and that arts organisations would have to find their own sources of funding through private sponsorship to pay for events that would be badged as part of the Cultural Olympiad (Calvi, 2007b) (raising the charges of opportunism that were also aired about some Sydney events). In late 2007, the government tried to assuage the negative reaction to these moves by announcing a repayment scheme, whereby after the games had finished, the selling-off of the land around the Olympic Park would allow the return of UK $£ 675$ million to the National Lottery, thus replenishing the arts funding coffers.

In effect, the structure of DCMS had contained the potential to span - to some extent the chasm between the worlds of arts and sports. But under almost inevitable budgetary pressures, this possible bridge was turned into a funnel which allowed transmission of resources away from arts and towards sports. The funnel was also easily constructed because of the New Labour definition of arts as 'cultural industries' 
- not a sector that needs subsidies but as a series of money-making endeavours that can and should function under their own financial steam (Alexander and Rueschemeyer, 2005).

Reflecting on this situation, the playwright Mark Ravenhill (2007), an important player in London's arts scene, brings us back to the sorts of social-structural and ideological issues which ultimately underpin - and indeed also undermine - attempts to make arts and sports work together in unison:

... the current battle over who gets public money - the arts or sport - runs a lot deeper than the run-up to the 2012 Olympics. It reflects a much wider split in our culture, a culture in which we can't imagine the poet competing in an international javelin event, or the gold medal breast stroke champion composing an opera .... our culture asks us to make a choice. Are we the hearty, rather thick people who excel physically? Or are we the sensitive and rather frail types who produce art? It's almost impossible to be both.

\section{Conclusion}

The title of this paper refers to the Greek word agon, which means 'sportive contest'. The agones were the athletics competitions of ancient Greek athletes (each an agonistes - a sportive combatant), including those competing at the original Olympic games. In modern times, it is not only athletes who engage in combats and struggles at the Olympics - artists of all varieties and arts administrators also engage in contests, this time for funding, for audiences and for media exposure. An essential structural feature of modernity - a condition now spread across the world - is that an agon exists between the arts on the one side and sports on the other. The idealistic tenets of Olympism have endeavoured to make both arts and sports into members of the same team, pulling together in the same direction But powerful forces - of social structure, of money, of vested interests, and of the twin ideologies of arts snobbism and sportive philistinism - work to pull them apart, and to place them once more into the roles of antagonists (a word also derived from agon), if not outright enemies.

As Garcia (2000) argues, the Olympic Games are 'both a great opportunity and a great threat for the development and exposure of visual arts exhibits and cultural performances in general'. The same may be said .of the more general arts-culturesport interface, both in cultural policy and in socio-cultural life itself. While the historical odds are weighted against arts and sports being wholly comfortable bedfellows, nonetheless under certain conditions they can at least lie in the same bed or be members of the same team. In terms of the specific case of Cultural Olympiads, the key issue is that the promises made in bids by given cities need to be kept, especially as regards funding. Over the last decades, promises have become ever bigger, at the same time as core infrastructure projects go over budget and gobble up money that should have been ring-fenced for cultural events. Better accountancy from the beginning, and less ambitious bids vis-a-vis the cultural programme would seem to be necessary components of a workable Cultural Olympiad strategy. The IOC should start to look more sceptically at grand claims being made by prospective host cities for the Cultural Olympiad, and should reward bids that are carefully-budgeted and modestly-scaled, whilst also exhibiting imagination and intellectual (as opposed to economic) ambition. Less is more, especially when money is spent wisely. 
It is also the case that host governments and local organising committees need to think long and hard as they prepare their bids as to how to coordinate the sports and arts programmes. Sydney organisationally divided these up too much - and ended up reproducing the arts/sports split that lies at the heart of all the problems we have encountered in this paper. The UK government, by contrast, has used the potentially beneficial structure of DCMS to raid the arts coffers to compensate for the sports infrastructure overspend, proving that forced de-differentiation of arts and sports does not work positively either. Their integration has to be of mutual benefit to both, not to the detriment of one or the other (especially as the art sphere is likely always to be the financial loser - see Stevenson, 1997).

Perhaps such lessons are too late to save the London events from repeating many of the mistakes of the past. But as a general rule, in the future it would very much help if all interested parties - cultural policy-makers, government officials, sports organisation workers, artists, arts administrators, and so on - paid more attention to the deeper social structural reasons that both underpin what they do and how they think, and which make the arts-culture-sports nexus, while potentially so fruitful, also so utterly problematic. It seems unlikely that de Coubertin's vision will ever be fully realised, within the context of the Olympics or elsewhere. Yet it remains a noble ideal to be aimed at, not least because it challenges some of the key social forces of modernity that we might decide it is important to struggle against.

\section{References}

Alexander, V. and Rueschemeyer, M. (2005) Art and the State: The Visual Arts in Comparative Perspective, Basingstoke, Palgrave

Bennett, T. (1998) Culture: a reformer's science, London: Sage

Bourdieu, P. (1993) The Field of Cultural Production, Cambridge: Polity

Calvi, N. (2007a) 'Jowell under fire from voluntary groups over Olympics funding' http://www.thestage.co.uk/news/newsstory.php/16611

(2007b) 'Olympic organisers warn there's little cash for culture' http://www.thestage.co.uk/news/newsstory.php/16707

Cashman, R. (2006) The Bitter-Sweet Awakening: The Legacy of the Sydney 2000 Olympic Games, Sydney: Walla Walla Press

DCMS (2007a) 'Speech by Tessa Jowell - Culture and the Olympic Ideal' http://www.culture.gov.uk/reference_library/minister_speeches/2075.aspx

(2007b) 'Taking The Cultural Olympiad To The UK's Regions - Culture Minister Margaret Hodge Names Eight Creative Programmers For England' http://www.culture.gov.uk/reference_library/media_releases/2284.aspx 
Garcia, B. (2000) 'Olympic Arts Festivals and the Visual Arts', National Association for the Visual Arts Newsletter, September, NAVA, Sydney, pp. 4-5

(2001) 'Sport vs Arts in the Struggle for Visibility, Culture @ the Olympics, Vol. 3, Issue 3, pp.9-13

http://www.culturalolympics.org.uk/2001.html

Garcia, B. and Miah, A. (2000) 'Olympic Ideals and Disney Dreams: Opportunities and Constraints for Cultural Representation During Sydney's Opening Ceremony', Human Kinetics: Social Science and Sports News, November.

(2002) 'The Olympics is not a Sporting Event' Culture @. the Olympics, Vol. 4, pp. 4-6

http://www.culturalolympics.org.uk/2002.html

(2005) Culture @ the Olympics. Intangible, Invisible but Impacting'. Paper presented at Exploring Internationalism. Scotland Responds to London's Olympic vision for Culture in 2012, Centre for Cultural Policy Research, University of Glasgow http://www.beatrizgarcia.net/Refs/2005CCPR.pdf

Girginov, V. and Parry, J. (2005) The Olympic Games Explained, Routledge, London The Guardian (2007) 'Jowell to tell how Olympics funds will be repaid' http://www.guardian.co.uk/society/2007/jun/27/voluntarysector.olympics2012

(2007) 'Olympics Can Help UK Rebrand Itself, Says New Cultural Chief' http://www.guardian.co.uk/uk/2007/apr/27/olympics2012.olympicgames

Gold, M. and Revill, G. (2007) 'The Cultural Olympiads: Reviving the Panegyris' in Gold, J. R. and Gold, M. (eds.) Olympic Cities. City Agendas, Planning, and the World's Games, 1896 to 2016, London, Routledge

Hilton, C. Hitler's Olympics: The 1936 Berlin Olympic Games, London, The History Press

Hughson, J. (2004) 'Sport in the "City of Culture", International Journal of Cultural Policy, Volume 10, Number 3, November, pp. 319-330(12)

Hughson, J. and Inglis, D. (2004) 'Creative Industries' and the Arts in Britain: Towards a 'Third Way' in Cultural Policy?, International Journal of Cultural Policy Vol. 7. No. 3, pp. 457-478

London2012 (2007)

http://www.london2012.com/news/media-releases/2007/2007-06/london-2012outlines-vision-for-cultural-olympiad.php

London Councils (2007) http://www.londoncouncils.gov.uk/.../24julybriefingnot.doc

Muller, N. (2000) Pierre de Coubertin, 1893-1937: Olympism, Selected Writings, Lausanne, International Olympic Committee 
Ravenhill, M. (2007)

http://www.guardian.co.uk/politics/2007/apr/30/olympics2012.politicsandthearts

Stanton, R. (2000) The Forgotten Olympic Art Competitions, Victoria BC, Trafford

Stevenson, D. (1997) 'Olympic Arts: Sydney 2000 and the Cultural Olympiad', International Review for the Sociology of Sport, Vol. 32, No. 3, pp. 227-238

Sztompka, P. (1993) The Sociology of Social Change, Oxford, Blackwell

Tusa. J. (2007) 'A Cultural Olympiad? Great idea - now give us the money', The Observer, Features and reviews section, Sunday August 05 2007, p. 7 http://www.guardian.co.uk/artanddesign/2007/aug/05/art.artsfunding

Williams, R. (1977) Marxism and Literature, Oxford:, Oxford University Press

-- (1981) Culture, Glasgow, Fontana

\footnotetext{
${ }^{1}$ Both the Tusa and Hebron quotations come from Tusa (2007)

${ }^{2}$ House of Commons debates, $25^{\text {th }}$ June, 2007.
} 